\title{
Use of ENSO-Based Seasonal Rainfall Forecasting for Informed Cropping Decisions by Farmers in the SAT India
}

V. Nageswara Rao $\cdot$ P. Singh · J. Hansen · T. Giridhara Krishna · S. K. Krishna Murthy

17.1

\section{Introduction}

Dryland agriculture in India is practiced on 97 million ha of the cultivated area that supports $40 \%$ of the human population and $60 \%$ of livestock population by producing $44 \%$ of the food and fodder requirements. Even if India can achieve the full potential of irrigation in 139.5 million ha, still 75 million ha drylands would continue to depend on rainfall from southwest (SW) and northeast (NE) monsoons, characterized by high rainfall variability that cause most of production uncertainties. Thus dryland agriculture continues to play a crucial role in India's food security. However, productivity gains have been relatively insignificant and risk-averse dryland farmers have to improve agricultural productivity with suitable management options and matching application of farm inputs to maximize crop productivity and income, while minimizing crop failure and input losses against uncertainties of seasonal weather to feed the booming population.

\section{2}

\section{Advances in Seasonal Climate Forecasting}

Sir Walker's early pioneering efforts in making long range forecasting of monsoon rainfall in India, led to several concepts on teleconnection and statistical relations in the field of climate forecasting especially the El Niño-Southern Oscillation (ENSO). Shukla and Paolino (1983) studied relations of Southern Oscillation on possibility of long range forecasting of Indian summer monsoon rainfall. Ropelewski and Halpert $(1987,1996)$ established better correlation of Pacific Ocean sea surface temperatures (SSTs) compared to Indian Ocean SSTs with rainfall variability in Indian subcontinent which also indicated the skill of October-November-December (OND) seasonal rainfall prediction in southern India. Both these efforts were focused on understanding the ENSO dynamics on slowly varying equatorial ocean temperatures, and established relationships to their manifestations on changing atmosphere and observed climate variability.

Virmani et al. (1982) estimated seasonal rainfall probabilities using statistical models for many locations in the semi-arid India. Gadgil et al. (1999) identified stronger relationship between El Niño years and rainfall in Anantapur compared to all-India summer monsoon rainfall from their analyses on seasonal rainfall from 1911-1998. Stone et al. (2000) demonstrated statistical methods to generate rainfall probabilities of climate forecasts from general circulation model (GCM)-derived southern oscillation index $(S O I)$ phases that are useful inputs for agricultural simulations to derive 
management decision options. Predictability of climate at regional scale presents an opportunity to identify feasible alternatives to mitigate the climate risks, improve productivity and food security.

\section{3 \\ Advances in Crop Modeling}

Comprehensive systems simulation models can simulate the dynamic processes of crop growth and development capturing their dynamic and nonlinear interactions with environmental variables. Agricultural Production Systems sIMulator (APSIM) (Mc Cown et al.1996) is a cropping systems model suite, which was developed and validated across several environments, especially, in the semi-arid tropics. Hammer et al. (1996) analyzed the skill of seasonal climate forecasting in the management of wheat crop with fixed and tactical decisions of applying $\mathrm{N}$ in a highly variable climate to increase profit and minimize risk. Gadgil et al. (1999), through their simulation work on "Farming Strategies for a Variable Climate", anticipated considerable impact of seasonal rainfall forecasting on farm-level decisions of peanut growers in Anantapur using DSSAT. Carberry et al. (2000) demonstrated through a simulation case study that SOI contributed skill in improving crop management decisions over two-year rotations in Australia. Using APSIM simulation analyses, Nageswara Rao et al. (2004) showed that intercropping of peanut with short duration (SD) pigeonpea can minimize the risk of crop failure, and verified this concept for two years in farmers' fields in several villages of Anantapur during the period 1999-2002. APSIM model has been successfully used for climate forecast based agricultural/crop management options across several countries including, India (Gadgil et al. 2002) and Australia (Carberry et al. 2000; Meinke and Hochman 2000; Nelson et al. 2002) to deal with crop systems/management options under varying environmental conditions without much limitations for data requirements. Recent advances in the predictability of seasonal climate and wider adaptability of cropping systems models to simulate crop yields based on seasonal climate forecasts, would provide opportunities for farmers to discuss several management options, before opting for a suitable crop management decision based on their available resources.

\section{4 \\ Overall Objective}

The overall objective of this study was to identify the skill of seasonal climate forecasts for the region and the value forecast skill for management decisions to minimizing the risk of climate variability on cropping systems' productivity.

\section{5}

\section{Specific Objectives}

1. To identify the ENSO relationship with seasonal rainfall and crop yields in the scarce rainfall zone of Andhra Pradesh, India.

2. To explore the potential value of seasonal rainfall forecasting for a range of improved cropping decisions. 
17.6

Study Area

We consider studying the potential of climate applications in Kurnool and Anantapur in the scarce rainfall of zone of Andhra Pradesh state in the southern peninsular India (Fig. 17.1) as farmers in these districts are mostly dependant on dryland agricultural incomes for their livelihoods and are often affected by crop losses and low incomes due to climate variability.

Kurnool district receives an annual rainfall of $\approx 640 \mathrm{~mm}$, ranging from 548 to $668 \mathrm{~mm}$ among different agro ecological situations, with a high coefficient of variation indicative of a high climate variability leading to uncertainties in crop production. Total rainfall in the crop season is received during two monsoon seasons (bi-model distribution): southwest (SW) monsoon during June-July-August-September (JJAS) and northeast (NE) monsoon during October-November-December (OND). Early season droughts during SW monsoon often result in first crop failure in this region. Yearto-year rainfall variability (Fig. 17.2, top panel), at the onset of southwest monsoon results in fluctuation in area sown and production of kharif sorghum and mungari cotton (Gossypium hirsutum sp.). Rainfall anomalies during NE monsoon (OND) pe-

Fig. 17.1. Study area and location of project villages in Kurnool and Anantapur districts of Andhra Pradesh, India

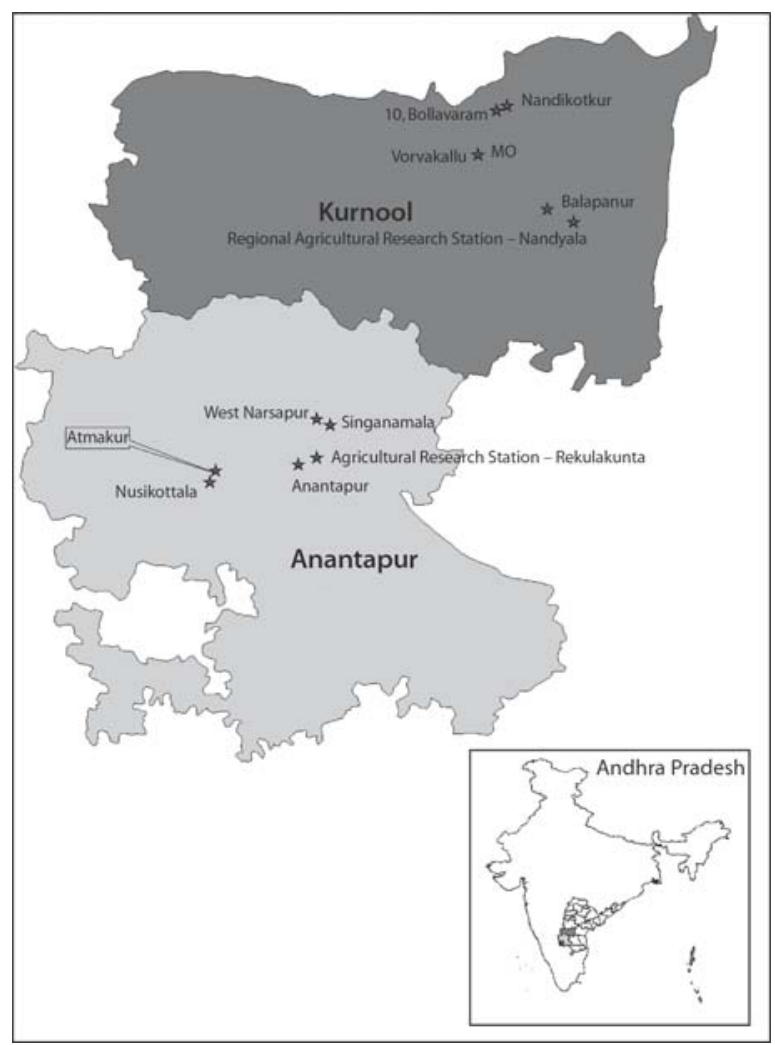


riod (Fig. 17.2, middle panel) influence area and production of chickpea and post-rainy sorghum, causing uncertainties of farm-income to resource-poor farmers. Soils in the Kurnool district are largely Vertisols or Vertic inceptisols with varying soil depth ranging from 90 to $150 \mathrm{~cm}$ with high clay or clay loamy calcareous soils. These soils can hold plant available soil water (PASW) ranging from 150-240 $\mathrm{mm}$ and possess high moisture retention capacities to support post rainy season drought tolerant crops like sorghum, sunflower, chickpea, and safflower are generally grown on stored soil moisture.

Normal rainfall for Anantapur district is low at $564 \mathrm{~mm}$, with rainfall variability ranges from 493 to $593 \mathrm{~mm}$ among different agro-ecological situations. Anantapur normally receives $60 \%$ of rainfall from SW monsoon (JJAS), $27 \%$ NE monsoon (OND) (a bi-model distribution), and seasonal anomalies especially in SW monsoon (Fig. 17.3, middle panel) influence the productivity of main crop peanut. Length of crop growing season is generally limited between 100 and 135 days by low rainfall and shallow Alfisols. Hence Anantapur typically represents the problems of dry land farming systems in the semi-arid to arid regions. Therefore, it was decided to determine the value of forecast skill for the region to convince stakeholders to utilize seasonal forecasts for crop management decisions.

\section{7}

\section{Approach}

\subsection{1}

\section{Climate Analyses and Seasonal Prediction}

Analyses were carried out to understand the relationships between ENSO and seasonal rainfall variability in the scarce rainfall region, especially with reference to Nandyala as well as Anantapur station weather observations. Records of historical rainfall of Nandyala (1950-2000) and Anantapur (1950-2000) were correlated with sea surface temperatures of the Niño 3.4 region (equatorial Pacific region between $120-170^{\circ} \mathrm{W}$ and $5^{\circ} \mathrm{N}-5^{\circ} \mathrm{S}$ as in Fig. 17.4) since 1950-2000.

We used three-month running-mean values of SST departures in the Niño 3.4 regions based on a set of improved homogeneous historical SST analyses (Extended Reconstructed SST-ERSST.v2, Smith and Reynolds 2003). National Oceanic and Atmospheric Administration's (NOAA) official operational definitions of El Niño and La Niña are as follows. El Niño is a phenomenon in the equatorial Pacific Ocean characterized by a positive sea surface temperature departure from normal (for the 1971-200o base period) in the Niño 3.4 region greater than or equal in magnitude to $0.5^{\circ} \mathrm{C}$ averaged over three consecutive months. La Niña is described as a phenomenon in the equatorial Pacific Ocean characterized by a negative sea surface temperature departure from normal (for the 1971-200o base period) in the Niño 3.4 region greater than or equal in magnitude to $0.5^{\circ} \mathrm{C}$ averaged over three consecutive months. As per these definitions of El Niño and La Niña, years were categorized as given in Table 17.1.

SW monsoon and NE monsoon rainfall for individual years as influenced by ENSO phase were also presented in Fig. 17.5ab, for both stations to visualize the signal for ENSO phase over two seasons in each year with circle indicating El Niño event, and triangle indicating La Niña. 


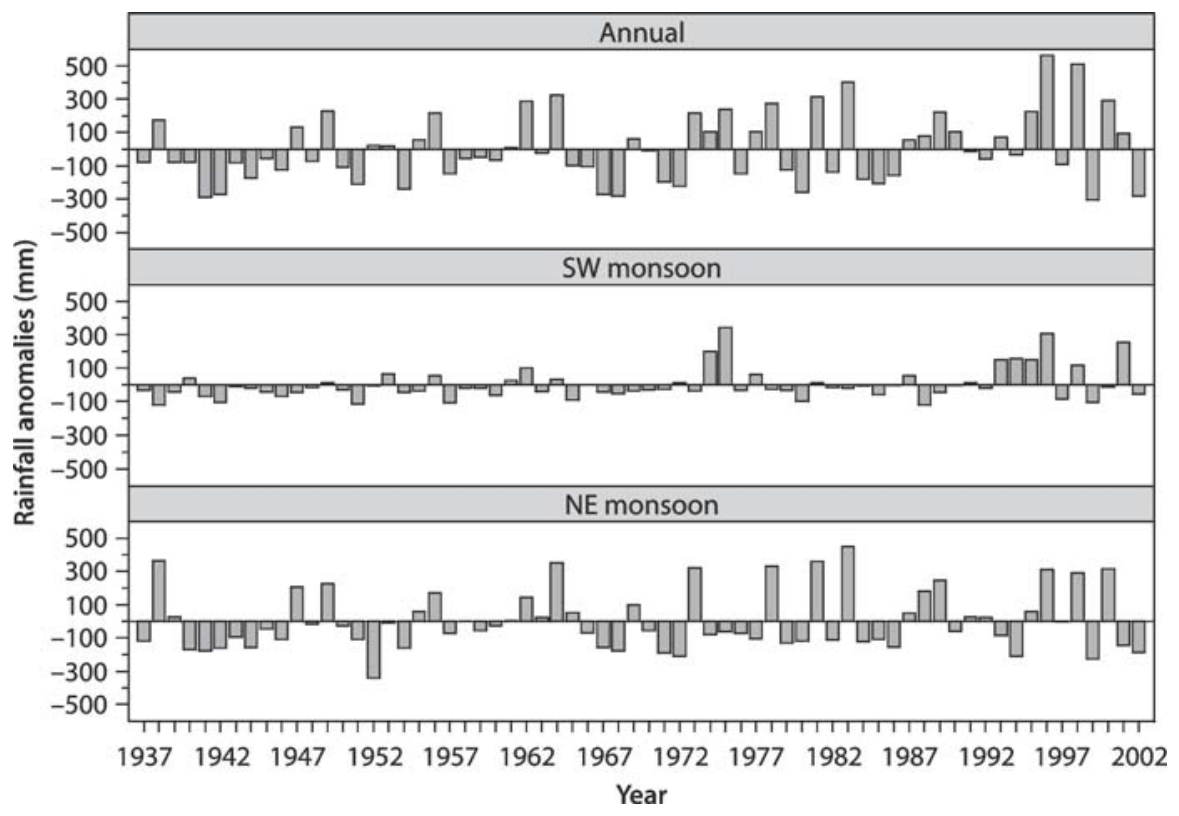

Fig. 17.2. Observed rainfall anomalies of annual, SW monsoon and NE monsoon periods since 1937 at RARS, Nandyala

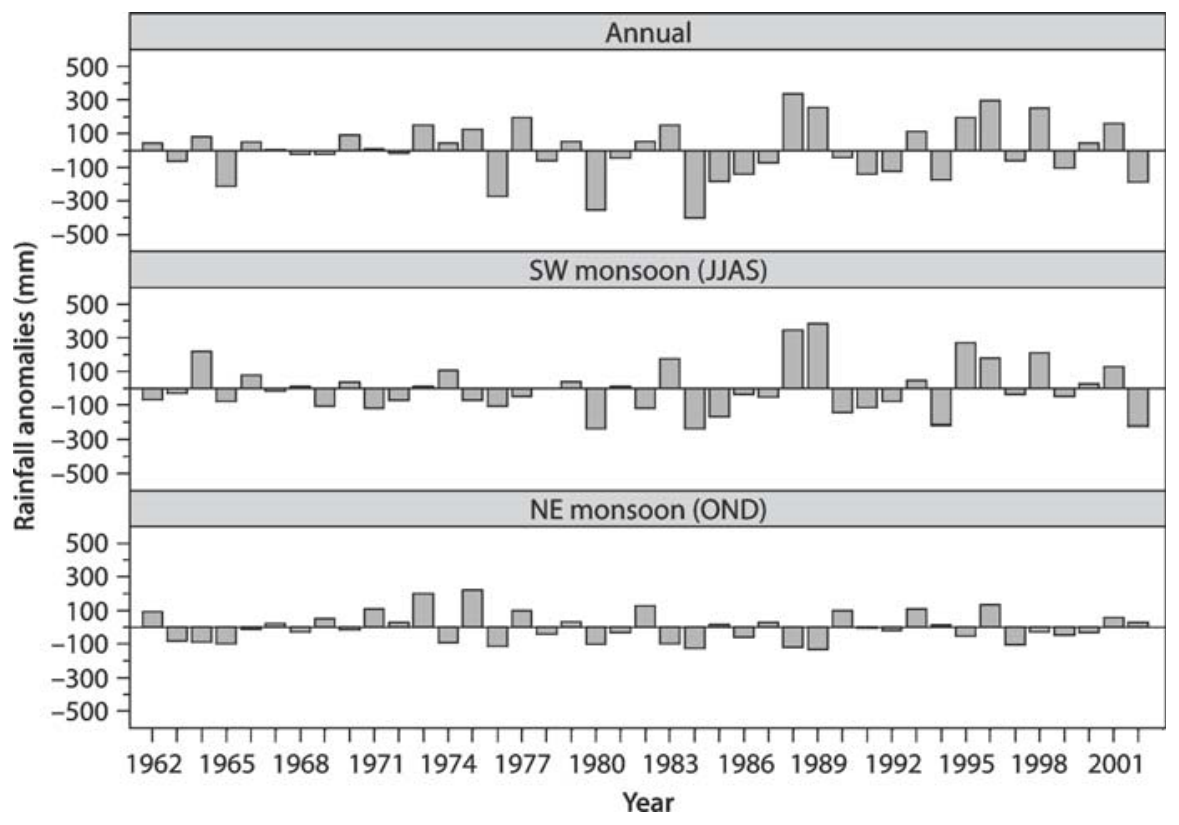

Fig. 17.3. Observed rainfall anomalies of annual, SW monsoon and NE monsoon periods since 1962 at ARS, Anantapur 


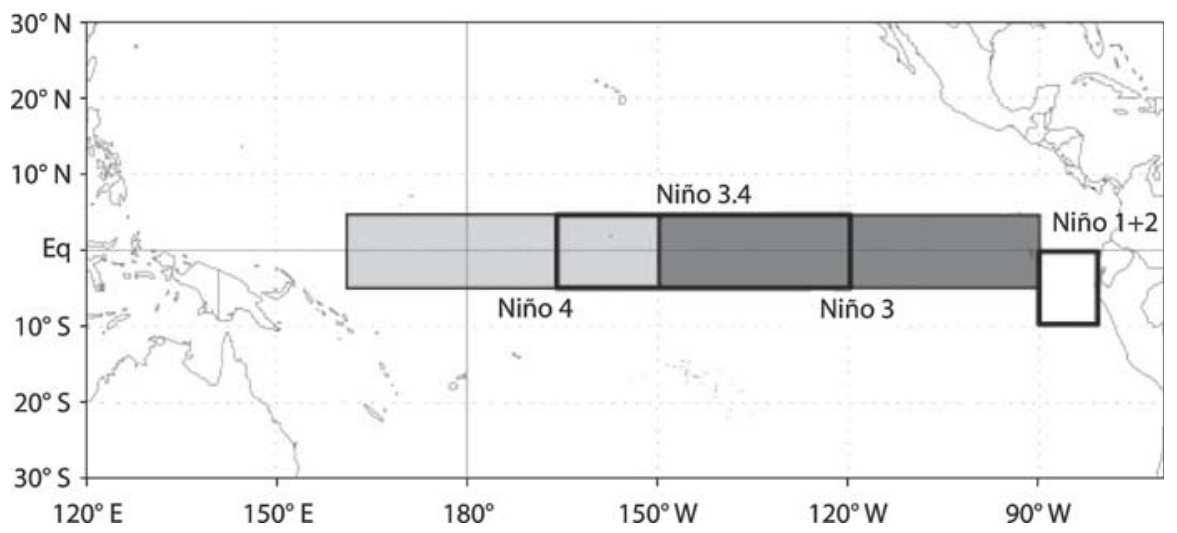

Fig. 17.4. Niño regions on the equatorial pacific as Niño 4 (light gray), Niño 3 (dark gray), Niño 3.4 (intersecting light and dark gray) and Niño $1+2$ (empty box) regions

Table 17.1. Year-wise categorization of ENSO phases from 1950 to 2002 based on NOAA's definition of El Niño and La Niña

\begin{tabular}{ll}
\hline ENSO phase & Years (SST anomaly maximum) \\
\hline El Niño (warm, low SOI) & $1951(0.7), 1957(1.6), 1963(1.0), 1965(1.6), 1969(0.7), 1972(2.1), 1976(0.8)$, \\
& $1977(0.8), 1982(2.3), 1986(1.2), 1987(1.6), 1991(1.8), 1993(0.8), 1994(1.3)$, \\
& $1997(2.5), 2002(1.5)$ \\
La Niña (cold, high SOI) & $1954(-1.1), 1955(-2.1), 1956(-1.2), 1964(-1.1), 1968(-0.9), 1970(-1.4)$, \\
& $1973(-2.0), 1975(-1.8), 1983(-0.9), 1985(-1.1), 1988(-1.9), 1989(-1.9)$, \\
& $1995(-0.8), 1998(-1.6), 2000(-1.6)$ \\
Neutral & $1950,1952,1953,1958,1959,1960,1961,1962,1966,1967,1971,1974,1978$, \\
& $1979,1980,1981,1984,1990,1992,1996,1999,2001$ \\
\hline
\end{tabular}

Based on ENSO phase, seasonal rainfall (JJAS and OND) was segregated for all years and the distribution of rainfall for each station is shown in box plots (Figs. 17.6 and 17.7) during three phases for Anantapur and Nandyala from 1950-2001.

Ropelewski and Halpert (1996) quantified global precipitation distributions in relation to Southern Oscillation (SO) and observed shifts in the percentiles of rainfall for the Indian subcontinent; with dry seasonal conditions during warm SSTs (low SOI) in the Pacific, and wetter seasonal conditions with cold SSTs (high SOI). Although ENSO is not the only factor influencing monsoon precipitations over the Indian subcontinent (Hastenrath 1987; Shukla and Mooley 1987), the close relationship between the SW monsoon rainfall and the ENSO phases are clearly seen (Fig. 17.6) in case of Anantapur. La Niña years' median (50\%) rainfall is well over total rainfall received $(<400 \mathrm{~mm})$ in that of any El Niño year, and more than $75 \%$ percentile of normal years. Median difference in rainfall is around $150 \mathrm{~mm}$ between El Niño and La Niña events which is crucial in any agricultural situation. While OND rainfall for Anantapur is low, El Niño and neutral years especially have a higher probability to receive more rainfall compared to the cold events. 
Fig. 17.5. a JJAS and OND seasonal rainfall distribution of Nandyala as affected by ENSO phase categories from 1950 to 2001; b JJAS and OND seasonal rainfall distribution of Anantapur as affected by ENSO phase categories from 1963 to 2001
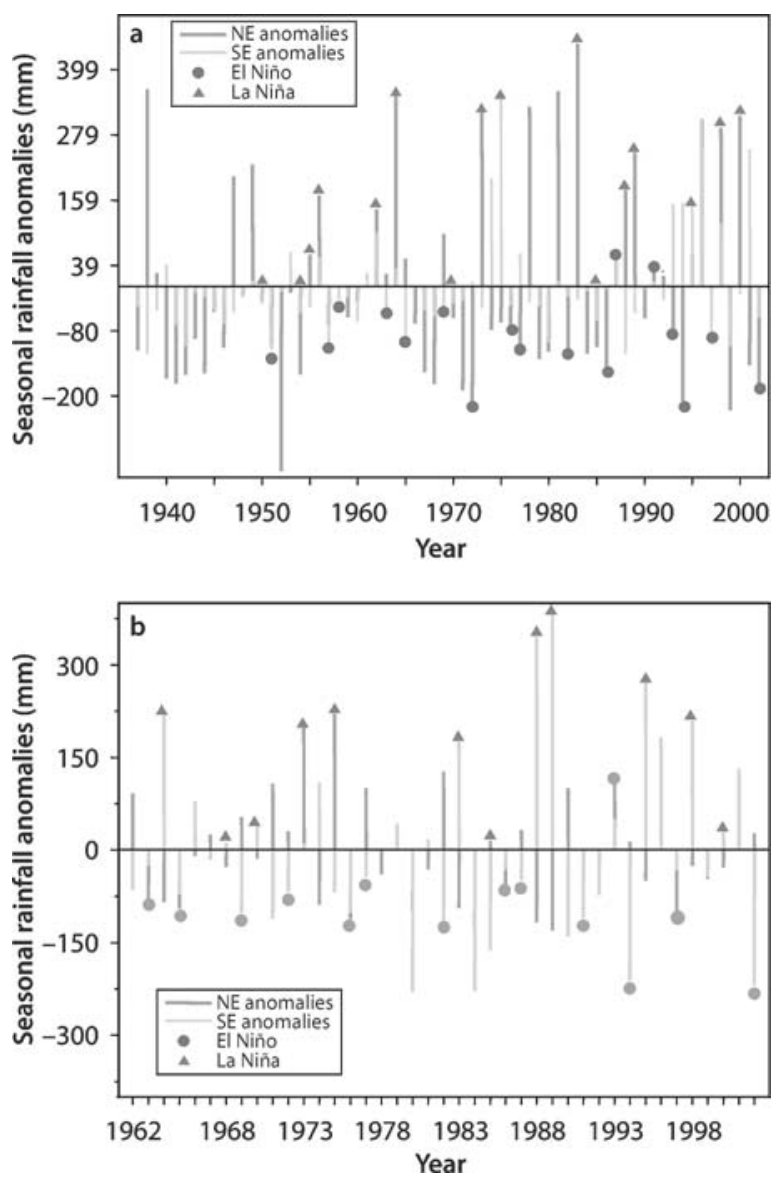

In case of Nandyala (Fig. 17.7), La Niña years receive higher rainfall with a median $<725 \mathrm{~mm}$ and approximately $900 \mathrm{~mm}$ can be expected in $25 \%$ percentile years, while during the El Niño and neutral years, the median remains same, just below $500 \mathrm{~mm}$. In winter months (OND), the median rainfall remains nearly at $100 \mathrm{~mm}$ with all phases, but the shift is towards higher rainfall in La Niña years as compared to neutral phase.

\subsection{2}

\section{Crop Yield Variability in Response to ENSO Phases}

Mungari cotton, kharif sorghum; peanut/pigeonpea intercrop systems have been the major crops cultivated in Kurnool during the SW monsoon season. Sunflower, chickpea and post rainy season sorghum are the major sequential crops grown during post rainy (NE monsoon) season. We analyzed the distribution of crop yields for each ENSO phase.

Crop yields were grouped based on the categorization of ENSO phases (Table 17.1) since 1950 to 2002. These yields were calculated from observed crop production in each 

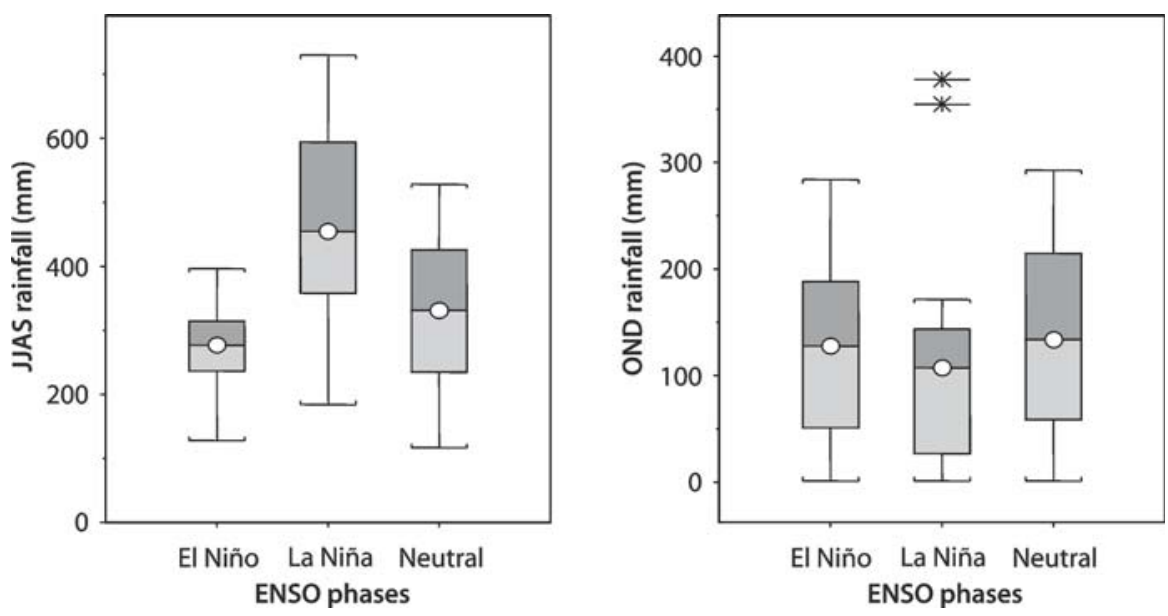

Fig. 17.6. Seasonal rainfall distribution of Anantapur as affected by ENSO phase categories from 1963 to 2001
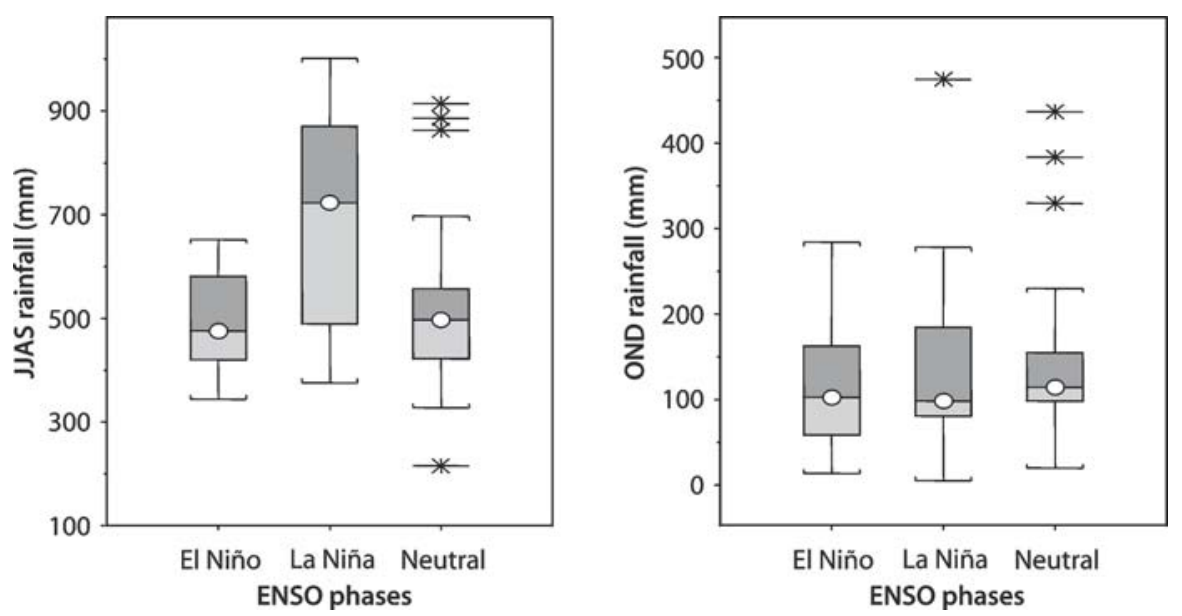

Fig. 17.7. Seasonal rainfall distribution of Nandyala as affected by ENSO phase categories from 1963 to 2001

district. This analysis provides inferences on the performance and likely adaptability of a crop once the ENSO phase is known, based on historically observed yields in different ENSO phases.

Box plots of crop yield distribution in different ENSO phases (El Niño, La Niña, neutral) indicate yield distribution of 25th percentile from bottom of the box (light gray) and 75th percentile to the top of the box (dark gray), with a circle connected by horizontal line in the middle of the box representing median (5oth percentile) of the crop yields time series. Bottom whisker cap indicates 1oth and top whisker indicates 
95th percentile of yield distribution. Horizontal lines with star or circle away from box plots are out-liers in the data representing a skewed distribution (Figs. 17.6 and 17.7).

In Kurnool, kharif sorghum median yield is above $\left(0.75 \mathrm{tha}^{-1}\right)$ during La Niña years, and distribution of sorghum yield in this phase ranged from 0.25 to $1.5 \mathrm{t} \mathrm{ha}^{-1}$ indicating that good rainfall distribution leads to higher yields in $50 \%$ of years and that sorghum yield in neutral years is also good compared to El Niño years (Fig. 17.8). Hence sorghum can be a rainy season crop option except in El Niño years. Contrary to expectations, mungari cotton yielded better in El Niño years compared to neutral or La Niña years, and can be a suitable crop option in El Niño years (Fig. 17.9). Peanut and pigeonpea intercrop system is an obvious choice in light soil areas of Kurnool during La Niña phase as the median yield for both the crops is conspicuously higher and yield addition in this phase is $>250 \mathrm{~kg} \mathrm{ha}^{-1}$ (Fig. 17.10ab). Chickpea and rabi sorghum have been two alternate crops for farmers of Kurnool as a sequential post rainy season crop, and both crops have different suitability options. While Chickpea yields were higher in El Niño years, its performance in La Niña is also consistently better than in neutral years (Fig. 17.11a). As opposed to this, sorghum median yields were higher and is a suitable option for this region in La Niña conditions (Fig. 17.11b).

Fig. 17.8. Rainy season sorghum yield as affected by rainfall in ENSO phases during 1950-2001 in Kurnool
Fig. 17.9. Mungari cotton yield as affected by rainfall in ENSO phases during 1950-2001 in Kurnool
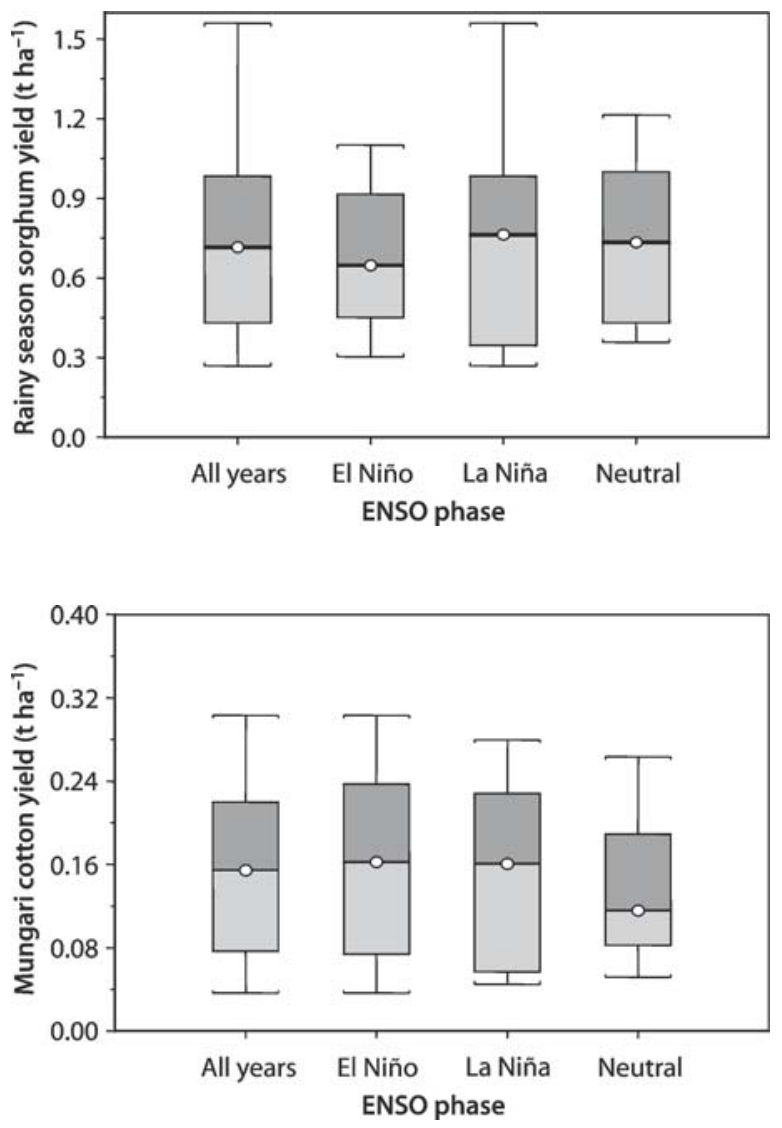
Fig. 17.10. a Peanut yield with intercrop as affected by rainfall in ENSO phases during 1950-2001 in Kurnool; b intercrop pigeonpea yield as affected by rainfall in ENSO phases during 1950-2001 in Kurnool
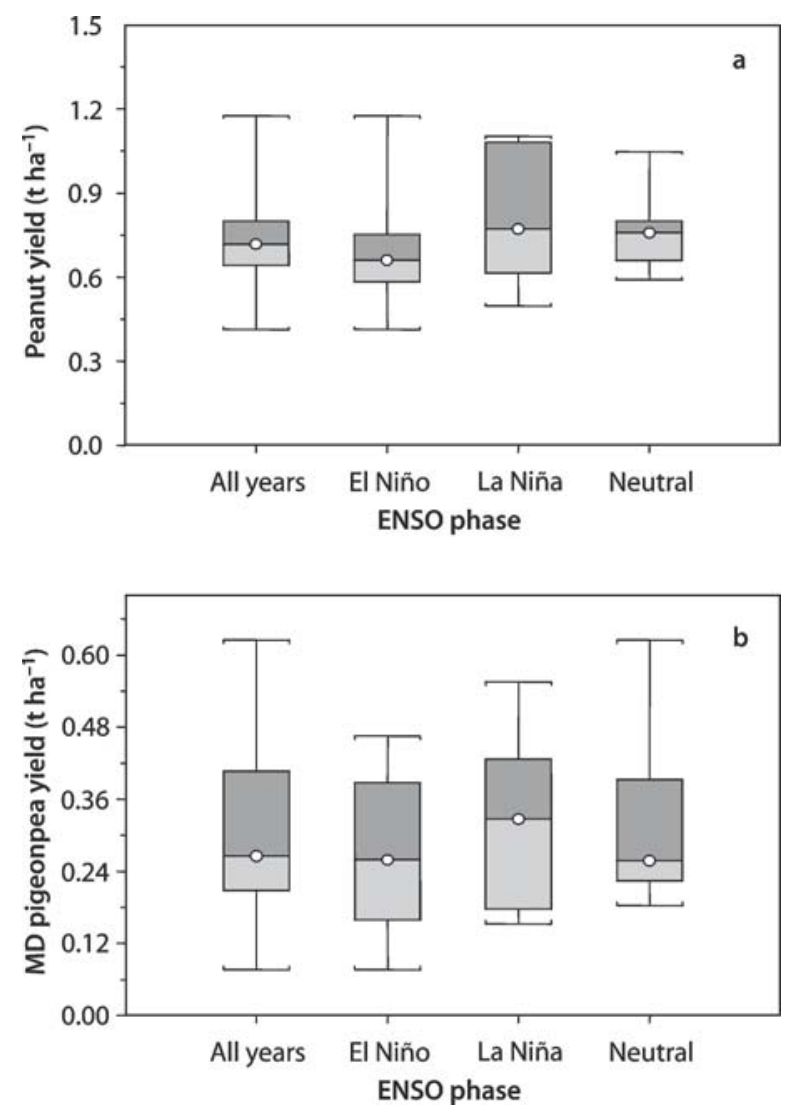

For Anantapur, ENSO phase wise crop yield analysis indicates that peanut/pigeonpea intercrop system (Fig. 17.12ab) additive performance would be higher in La Niña years $\left(>0.9 \mathrm{t} \mathrm{ha}^{-1}\right)$, but in neutral and El Niño years its median yields are low $\left(<0.7 \mathrm{tha}^{-1}\right)$ and remain below district mean yields (Fig. 17.12).

\subsection{3}

\section{Farmers' Decision Options}

Discussions with farmers of Kurnool and Anantapur were initiated with rapid appraisal survey jointly conducted by us in collaboration with the Regional Agriculture Research Station (RARS) scientists. These discussions with farmers were mainly aimed at understanding their perceptions on climate variability, seasonal rainfall dependent cropping management options, and availability and use of rainfall forecast information. Summary of key decisions which some of the farmers proposed to take based on the forecast information are listed in Table 17.2. 
Fig. 17.11. a Chickpea yield as affected by rainfall in ENSO phases during 1950-2001 in Kurnool; b post-rainy sorghum as affected by rainfall in ENSO phases during 1950-2001 in Kurnool
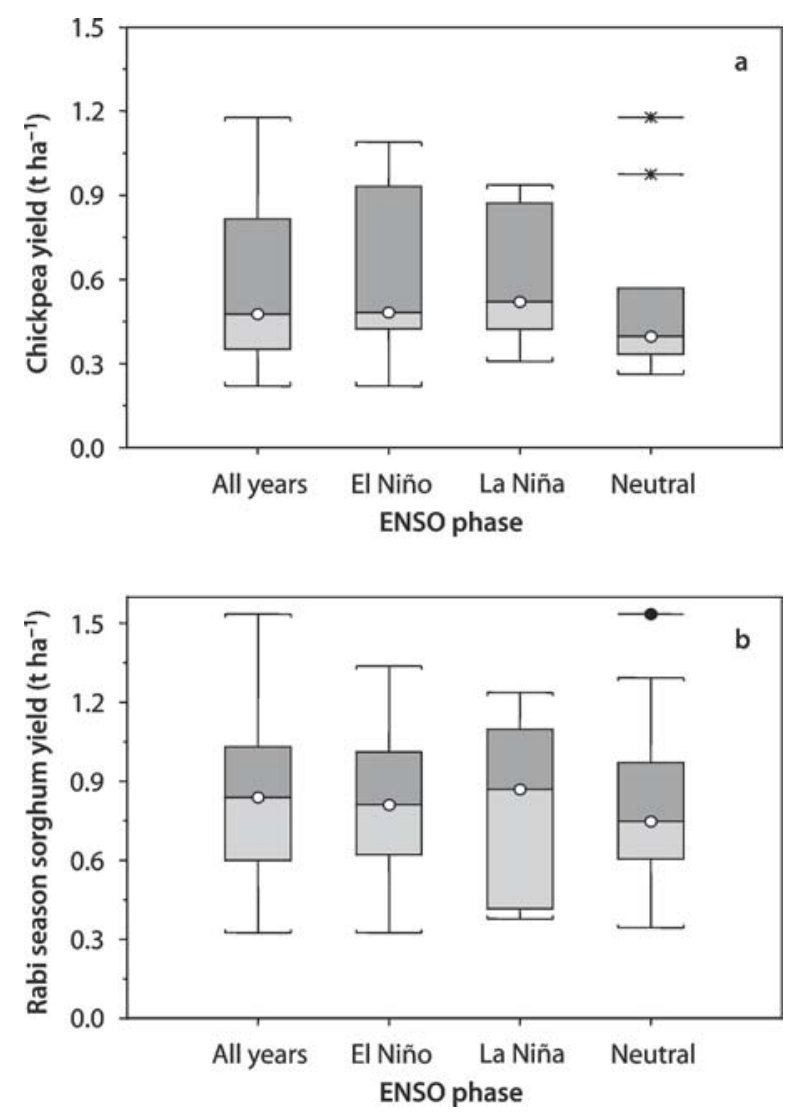

\subsection{4}

\section{Simulations of Cropping Systems}

APSIM (Mc Cown et al.1996), a cropping systems simulator capable of simulating several crops and cropping systems grown as sequential and intercrop systems in the project region, as well as "what if" management scenario analyses was used in this study. Daily-observed weather data from 1963 to 1998 for Anantapur, and from 1984 to 1998 for Nandyala were used for simulation input. Data sets available from experiments at RARS Nandyala, and ARS, Anantapur were used for cultivar parameterization to simulate crops. Cropping systems scenarios were simulated using observed daily weather data for all years as well as ENSO phase based analog years (Table 17.1) daily data to compare probable production estimates and the value of ENSO based seasonal forecasts was estimated to assess risks of loss/gain associated with cropping system in different phases. We could not use any optimization algorithm except arriving at the maximum mean of crop yield. 
Fig. 17.12. a Peanut yield in intercrop as affected by rainfall in ENSO phases during 1950-2001 in Anantapur; b intercrop pigeonpea yield as affected by rainfall in ENSO phases during 1950-2001 in Anantapur
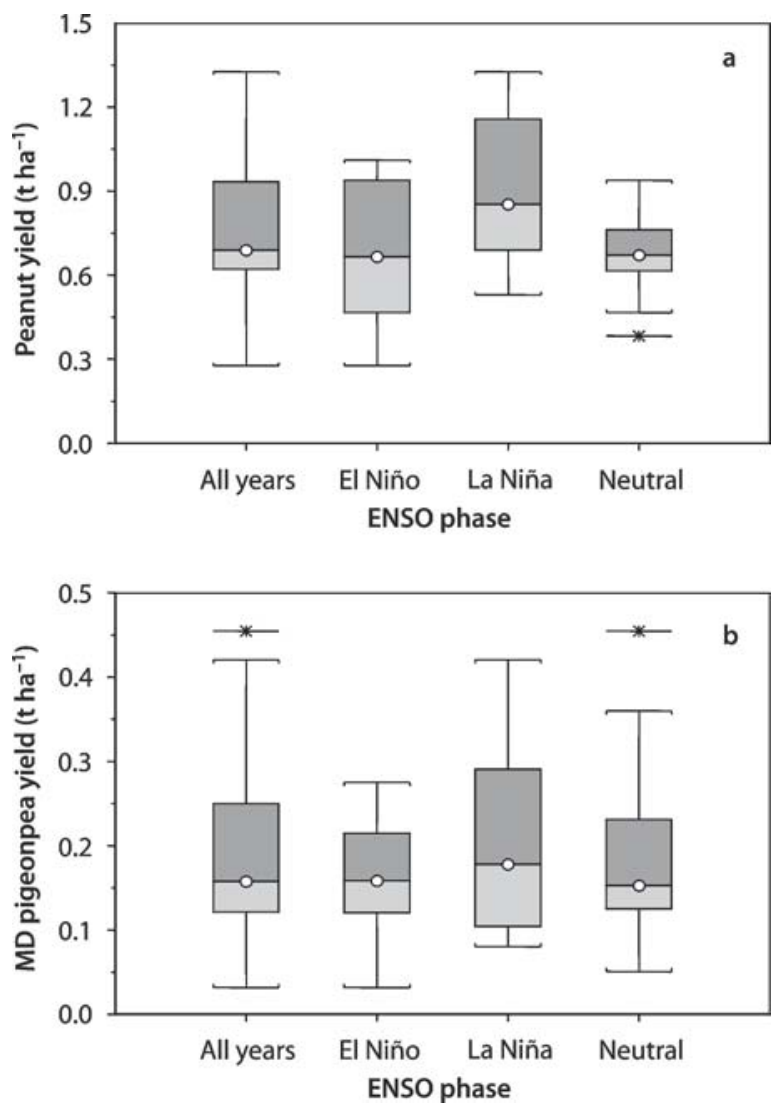

Table 17.2. Key issues in forecast that may lead farmers' decision options in Anantapur and Kurnool as against traditional/risk-averse decision cropping systems

\begin{tabular}{lll}
\hline Location/Forecast issue & Forecast based decision options & $\begin{array}{l}\text { Traditionally risk averse/ } \\
\text { low input decisions }\end{array}$ \\
\hline Anantapur & & \\
July rainfall & Peanut/pigeonpea intercrop & Sole peanut \\
Late/August rainfall & $\begin{array}{l}\text { Peanut/short duration pigeonpea } \\
\text { intercrop }\end{array}$ & $\begin{array}{l}\text { Sole peanut, SD pigeonpea, } \\
\text { sorghum, horse gram }\end{array}$ \\
Kurnool & $\begin{array}{l}\text { Mungari cotton, intercrops like } \\
\text { June rainfall and } \\
\text { good seasonal rainfall }\end{array}$ & $\begin{array}{l}\text { Mungbean + chickpea, } \\
\text { foxtail millet/pigeonpea, } \\
\text { munglowean + sorghum }\end{array}$ \\
& sunflower + chickpea sequence & Late sunflower, late sorghum \\
Late rainfall & Sole sunflower, sole chickpea & Wait for September rains \\
September-October rainfall & Sole rabi sorghum \\
\hline
\end{tabular}


Cropping systems scenarios include yield estimates of traditional practice of single crop systems for all seasons and optimized ENSO phase forecast based crop production estimates. Conceptualization of these system scenarios is based on the farmers' survey results as preferred and adoptable decision depending on seasonal forecast and soil conditions (Table 17.2) for Kurnool and Anantapur.

\subsection{5}

\section{Simulation Scenarios of Baseline Management}

We could simulate yield estimate of rainy season sorghum and sequential chickpea system in hindcast for all years as well as ENSO phase forecast considering analog years, with sowing opportunity triggered between 15 and 25 June, when 5 days accumulated rainfall exceeded $60 \mathrm{~mm}$ or extractable soil water was greater than $65 \mathrm{~mm}$ in the wet sowing zone of the soil for Kurnool region. Farmers usually apply two bags of fertilizer per acre in different N-P-K grades (18-46-0, 20-20-0, 17-17-17, 28-28-0), giving a nutrient application $\left(\mathrm{kg} \mathrm{ha}^{-1}\right)$ ranging from 42.5-70 N, 42.5-115 $\mathrm{P}_{2} \mathrm{O}_{5}$ and $42.5 \mathrm{~K}_{2} \mathrm{O}$. However, in simulations, we considered application of $80 \mathrm{~kg} \mathrm{~N} \mathrm{ha}^{-1}$ during La Niña and $40 \mathrm{~kg} \mathrm{~N} \mathrm{ha}^{-1}$ during El Niño and ENSO neutral for both the crop seasons as the optimal practice compared to baseline simulation of single crop kharif sorghum with $40 \mathrm{~kg} \mathrm{~N} \mathrm{ha}^{-1}$ application for all year.

In Anantapur, a sole crop peanut is traditionally grown by risk-averse farmers which is sown any time, but mostly from the 3 rd week of July to 2 nd week of August, with a fertilizer application at $20 \mathrm{~kg} \mathrm{~N} \mathrm{ha}^{-1}$ and this was considered as a baseline management simulation. We simulated peanut/medium duration pigeonpea cropping system with sowing triggered between 25 June and 21 July, and planting at a wide row ratio of 7:1 as the optimal management during the La Niña seasons. Peanut/medium duration pigeonpea intercrop was generally recommended for farmers to suit longer cropping season, and ICRISAT promoted peanut/short duration pigeonpea intercrop system as suitable for short seasons after carrying out systems analysis for Anantapur. During El Niño and ENSO neutral years, sowing opportunities were triggered between 15 July and 15 August with peanut/short duration pigeonpea intercrop system, at 3:1 to 7:1 row ratios under Anantapur conditions. Simulations were carried out with these intercrop systems using $40 \mathrm{~kg} \mathrm{~N} \mathrm{ha}^{-1}$ application using observed weather for the ENSO phase ana$\log$ years.

\subsection{6}

\section{Value of Seasonal Forecasting Skill}

The value of ENSO phase forecasting skill for crop management options was calculated for each ENSO phase with appropriate cropping system and management options. The potential value of optimal use of ENSO phase forecast is evaluated as the mean difference between the returns for optimal cropping system management for each ENSO phase in the time series and returns to all weather optimal cropping system management (Hansen et al. 2001). Inputs like seed and fertilizer cost, crop output prices and fixed costs are considered at the rates prevailing during March 2003, the end of crop season. Results are shown in Tables 17.3 and 17.4. 
Table 17.3. Estimated crop yields and value of ENSO phase information for peanut/pigeonpea intercrop system management as compared to all weather optimal sole peanut during 1963-1998 in Anantapur region

\begin{tabular}{|c|c|c|c|c|c|c|}
\hline \multirow{2}{*}{$\begin{array}{l}\text { ENSO } \\
\text { phase }\end{array}$} & \multirow{2}{*}{$\begin{array}{l}\text { No. of } \\
\text { years }\end{array}$} & \multirow[t]{2}{*}{ Cropping system } & \multicolumn{3}{|c|}{ Yield by ENSO phase } & \multirow{2}{*}{$\begin{array}{l}\text { Value } \\
\left(\text { Rs ha }^{-1}\right)\end{array}$} \\
\hline & & & $\begin{array}{l}\text { Peanut } \\
\left(\text { t ha }^{-1}\right)\end{array}$ & $\begin{array}{l}\text { Pigeonpea } \\
\left(\mathrm{tha}^{-1}\right)\end{array}$ & $\begin{array}{l}\text { Net } \\
\text { (Rs ha }^{-1} \text { ) }\end{array}$ & \\
\hline El Niño & 13 & $\begin{array}{l}\text { Peanut/SD } \\
\text { pigeonpea }\end{array}$ & 0.65 & 0.21 & 12000 & 584 \\
\hline La Niña & 11 & $\begin{array}{l}\text { Peanut/MD } \\
\text { pigeonpea }\end{array}$ & 1.22 & 0.22 & 19040 & 7824 \\
\hline Neutral & 12 & $\begin{array}{l}\text { Peanut/SD } \\
\text { pigeonpea }\end{array}$ & 0.830 & 0.35 & 17080 & 5664 \\
\hline All years & 36 & Sole peanut & 0.868 & - & 10416 & - \\
\hline
\end{tabular}

Table 17.4. Estimated crop yields and value of ENSO phase information for sorghum + chickpea crop management as compared to all weather optimal sole chickpea during 1963-1998 in Kurnool region

\begin{tabular}{|c|c|c|c|c|c|c|}
\hline \multirow{2}{*}{$\begin{array}{l}\text { ENSO } \\
\text { phase }\end{array}$} & \multirow{2}{*}{$\begin{array}{l}\text { No. of } \\
\text { years }\end{array}$} & \multirow[t]{2}{*}{ Cropping system } & \multicolumn{3}{|c|}{ Yield by ENSO phase } & \multirow{2}{*}{$\begin{array}{l}\text { Value } \\
\left(\mathrm{Rs} \mathrm{ha}^{-1}\right)\end{array}$} \\
\hline & & & $\begin{array}{l}\text { Sorghum } \\
\left(\text { t ha }^{-1}\right)\end{array}$ & $\begin{array}{l}\text { Chickpea } \\
\left(\mathrm{t} \mathrm{ha}^{-1}\right)\end{array}$ & $\begin{array}{l}\text { Net } \\
\text { (Rs ha }^{-1} \text { ) }\end{array}$ & \\
\hline El Niño & 13 & $\begin{array}{l}\text { Rainy season } \\
\text { sorghum with rabi } \\
\text { chickpea }\end{array}$ & 0.67 & 0.94 & 12000 & 160 \\
\hline La Niña & 11 & $\begin{array}{l}\text { Rainy season } \\
\text { sorghum with rabi } \\
\text { chickpea }\end{array}$ & 1.2 & 1.0 & 19040 & 5600 \\
\hline Neutral & 12 & $\begin{array}{l}\text { Rainy season } \\
\text { sorghum with rabi } \\
\text { chickpea }\end{array}$ & 1.1 & 0.6 & 17080 & $(-3200)$ \\
\hline All years & 36 & Sole chickpea & - & 1.2 & 10416 & - \\
\hline
\end{tabular}

\section{8 \\ Results and Discussion}

ENSO phases have a considerable influence on the seasonal rainfall of Kurnool and Anantapur districts in the scarce rainfall zone of Andhra Pradesh, India. All La Niña phases produced higher rainfall than normal rainfall in both districts in the ensuing monsoon season, and lower rainfall during following monsoon season in all El Niño phases in both districts but for two years in Kurnool (Fig. 17.5a.). Historical crop yields of rainy season sorghum, peanut/pigeonpea intercrops were positively affected by the La Niña phase seasons, indicating that good rainfall distribution leads to higher yields in $50 \%$ of the years. Sorghum yield in neutral years is also higher compared to El Niño 
years (Fig. 17.8). Hence sorghum can be a rainy season crop option except in El Niño years. Contrary to expectations, mungari cotton yielded better in El Niño years compared to neutral or La Niña years. Cotton is a deep rooted and long duration crop with standing moisture stress and solar radiation may the factor favoring in El Niño phases, and it can be a suitable crop option in El Niño years (Fig. 17.9). Peanut and pigeonpea intercrop system is an obvious choice in the light soil areas of Kurnool and Anantapur during the La Niña phase as the median yield for both the crops is conspicuously higher and the yield increase in this phase was $>250 \mathrm{~kg} \mathrm{ha}^{-1}$ (Figs. 17.10 and 17.12). While chickpea yields were higher in El Niño years, its performance in La Niña was also consistently better than in neutral years (Fig. 17.11a). For Anantapur, ENSO phase wise crop yield analysis indicates that the additive performance of peanut/pigeonpea intercrop system (Fig. 17.12ab) would be higher in La Niña years $\left(>0.9 \mathrm{t} \mathrm{ha}^{-1}\right)$, but low $\left(<0.7 \mathrm{t} \mathrm{ha}^{-1}\right)$ during neutral and El Niño years (Fig. 17.12). Value of ENSO phase forecasting skill (Tables 17.3 and 17.4) has been higher in La Niña phase in both districts at Rs 7564 for peanut median duration pigeonpea in Anantapur and Rs 5600 for sorghum + chickpea sequential systems in Kurnool. During the El Niño phase, forecasting has the lowest value since optimal crop management with low input applications resulted in low yields as it was limited by moisture availability.

\section{9}

\section{Conclusions}

Through the identification of the relationship between ENSO phase based on extended reconstructed SSTs and seasonal observed weather for a small and agriculturally homogeneous region, the utility of climate forecasts in agricultural decision-making options has been established for a scarce rainfall region in Andhra Pradesh, India. Since ENSO phase analyses is the simplest method for identifying the forecast skill for the region, we used this study as a preliminary approach to sensitize farmers for seasonal climate forecast based crop management options evaluation. However the optimal crop management options presented in the study are limited and several other cropping options need to be explored.

\section{References}

Carberry P, Hammer G, Meinke H, Bange M (2000) The potential value of seasonal climate forecasting in managing cropping systems. In: Hammer GL, Nicholls N, Mitchell C (eds) Applications of seasonal climate forecasting in agricultural and natural ecosystems. Kluwer Academic Publishers, Dordrecht, The Netherlands

Gadgil S, Seshagiri Rao PR, Narahari Rao K, Savithri K (1999) Farming strategies for a variable climate. Center for Atmospheric and Oceanic Sciences, Indian Institute of Sciences, Bangalore, India (CAOS Report 99AS6)

Gadgil S, Seshagiri Rao PR, Narahari Rao K (2002) Use of climate information for farm-level decision making: rainfed groundnut in southern India. Agr Syst 74(3):431-457

Hammer GL, Holzworth DP, Stone R (1996) The value of skill in seasonal climate forecasting to wheat crop management in a region with high climate variability. Aust J Agr Res 47:717-737

Hansen JW, Jones JW, Irmak A, Royce F (2001) El Niño-Southern Oscillation impacts on crop production in the southern United States. In: Rosenzweig C (ed) Impacts of El Niño and climate variability on Agriculture. American Society of Agronomy (ASA), Madison, WI, USA (ASA Special Publication 63, pp 55-76)

Hastenrath S (1987) On the prediction of Indian monsoon rainfall anomalies. J Clim Appl Meteorol 26:847-857 
Mc Cown RL, Hammer GL, Hargreaves JNG, Holzworth DP, Freebairn DM (1996) APSIM: a novel software system for model development, model testing and simulation in agricultural research. Agr Syst 50:255-271

Meinke H, Hochman Z (2000) Using seasonal climate forecasts to manage dryland crops in northern Australia. In: Hammer GL, Nicholls N, Mitchell C (eds) Applications of seasonal climate forecasting in agricultural and natural ecosystems. Kluwer, Dordrecht, The Netherlands, pp 149-165

Nageswara Rao V, Singh P, Balaguravaiah D, Dimes JP, Carberry P (2004) Systems modeling and farmers' participatory evaluation of cropping options to diversify peanut systems in Anantapur region, India. I: APSIM simulations to analyze constraints and opportunities. In: New directions for a diverse planet. Handbook and Abstracts for the 4th International Crop Science Congress, Brisbane, Australia

Nelson RA, Holzworth DP, Hammer GL, Hayman PT (2002) Infusing the use of seasonal climate forecasting into crop management practices in North East Australia using discussion support software. Agr Syst 74:393-414

Ropelewski CF, Halpert M (1987) Global and regional scale precipitation patterns associated with the El Niño/Southern Oscillation. Mon Weather Rev 115:1606-1626

Ropelewski CF, Halpert M (1996) Quantifying Southern Oscillation-precepitation relationships. J Climate 2:268-284

Shukla J, Mooley DA (1987) Empirical prediction of the summer monsoon rainfall over India. Mon Weather Rev 115:695-703

Shukla J, Paolino DA (1983) The Southern Oscillation and long range forecasting of the summer monsoon rainfall over India. Mon Weather Rev 111:1830-1837

Smith TM, Reynolds RW (2003) Extended reconstruction of global sea surface temperatures based on COADS data (1854-1997). J Climate 16:1495-1510

Stone R, Smith I, McIntosh P (2000) Statistical methods for deriving seasonal climate forecasts from GCMs. In: Hammer GL, Nicholls N, Mitchell C (eds) Applications of seasonal climate forecasting in agricultural and natural ecosystems. Kluwer, Dordrecht, The Netherlands, pp 135-147

Virmani SM, Sivakumar MVK, Reddy SJ (1982) Rainfall probability estimates for selected locations of semi-arid India. International Crops Research Institute for the Semi-Arid Tropics (ICRISAT), Patancheru, Andhra Pradesh, India (Research Bulletin 1) 